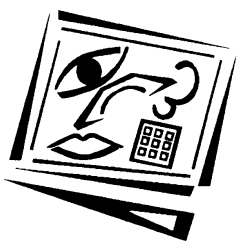

\title{
Personalised and self regulated learning in the Web 2.0 era: International exemplars of innovative pedagogy using social software
}

\author{
Catherine McLoughlin \\ Australian Catholic University \\ Mark J. W. Lee \\ Charles Sturt University
}

An Outstanding Paper Award recipient, ascilite Auckland 2009 Conference

\begin{abstract}
Research findings in recent years provide compelling evidence of the importance of encouraging student control over the learning process as a whole. The socially based tools and technologies of the Web 2.0 movement are capable of supporting informal conversation, reflexive dialogue and collaborative content generation, enabling access to a wide raft of ideas and representations. Used appropriately, these tools can shift control to the learner, through promoting learner agency, autonomy and engagement in social networks that straddle multiple real and virtual learning spaces independent of physical, geographic, institutional and organisational boundaries. As argued in this article, however, in order for self-regulated learning to come to fruition, students need not only to be able to choose and personalise what tools and content are available, but also to have access to the necessary scaffolding to support their learning. Emerging practices with social computing technologies, a number of examples of which are showcased in this article, signal the need for pedagogies that are more personal, social and participatory. The authors conclude with a discussion of some of the key implications for practice, including an outline of the current challenges faced by tertiary educators.
\end{abstract}

\section{Web 2.0 and the trend towards self directed learning environments}

The global learning landscape of the twenty-first century is being transformed and shaped by the uptake of digital communication tools and ubiquitous networked applications, along with the changing characteristics, needs and demands of students. The UK-based Committee of Inquiry into the Changing Learner Experience (CLEX, 2009) concludes that

Web 2.0, the Social Web, has had a profound effect on behaviours, particularly those of young people whose medium and metier it is. They inhabit it with ease and it has led them to a strong sense of communities of interest linked in their own web spaces, and to a disposition to share and participate. (p. 9)

This indicates that digital-age students want an active learning experience that is social, participatory and supported by rich media. Current research also points to a growing appreciation of the need to support and encourage learner control over the whole/entire learning process (Dron, 2007). As web based multimedia production and 
distribution tools incorporating text (blogs, wikis, Twitter), audio (podcasting, Skype), photo (Flickr) and video (vodcasting, YouTube) capabilities continue to grow, tertiary education institutions are faced with ever expanding opportunities to integrate social media and technologies into teaching, learning and assessment. If employed in conjunction with appropriate strategies, learning technologies are capable of supporting and encouraging informal conversation, dialogue, collaborative content generation and the sharing of knowledge, thereby opening up access to a vast array of representations and ideas. Many social software tools afford greater agency to the learner by allowing autonomy and engagement in global communities where ideas are exchanged and knowledge is created as students assume active roles (Lee, McLoughlin \& Chan, 2008; Ashton \& Newman, 2006).

The learning experiences that are made possible by social software tools are active, process based, anchored in and driven by learners' interests, and therefore have the potential to cultivate self regulated, independent learning. Self regulated learning (Biggs, 1987; Zimmerman \& Schunk, 1989; Simons 1992) refers to the ability of a learner to prepare for his/her own learning, take the necessary steps to learn, manage and evaluate the learning and provide self feedback and judgment, while simultaneously maintaining a high level of motivation. A self regulated learner is able to execute learning activities that lead to knowledge creation, comprehension and higher order learning (Stubbé \& Theunissen, 2008) by using processes such as monitoring, reflection, testing, questioning and self evaluation. The quest for learning to be 'student centred', self directed and self regulated has long been a pursuit of educators, and recent reports from various countries including the UK (see Owen, Grant, Sayers \& Facer, 2006; Bryant, 2007; Minocha, 2009; CLEX, 2009), USA (see New Media Consortium, 2006, 2007, 2008, 2009; Salaway, Caruso \& Nelson, 2008) and Australia (see Fitzgerald \& Steele, 2008) indicate that the integration of social software into learning design can make a qualitative difference to giving students a sense of ownership and control over their own learning and career planning. However, universities and colleges still tend to rely on conservative, established course management systems (CMSs) and virtual learning environments (VLEs) that do not fully capitalise on the potential of social media that enable participation in global learning networks, collaboration and social networking. Of late, the personal learning environment (PLE) has emerged as a concept associated with the adoption of a raft of Web 2.0 tools that serves to integrate essential learning outcomes such as lifelong learning, informal learning and self directed learning.

\footnotetext{
The most compelling argument for the PLE is to develop educational technology which can respond to the way people are using technology for learning and which allows them to ... shape their own learning spaces, to form and join communities and to create, consume, remix, and share material" (Attwell, 2006a, "What about educational technology?", para. 8).
}

In this article, we consider issues pertaining to the design of personalised learning spaces, resources and environments using social software and media, and how they might be used to promote and achieve learner self direction. Of crucial importance to attaining the longstanding goal of student centred learning is the need to acknowledge the importance of including informal modes of learning in the learning experience, to realise that learner needs and preferences cannot be addressed as static constructs during the design and development phases of instructional design, and to provide suitable scaffolds to support the learning outcomes to be attained. Educators need to revisit socially based, conversationally driven designs for self directed learning and be 
prepared to accept and face the reality that learners' needs, preferences, perceptions and mental models will contribute significantly to the dynamic process that is learning design. This implies that pedagogic change and greater personalisation of learning are both necessary for student centred, self regulated and independent learning.

\section{Personalisation and personal learning environments}

Although many CMSs and VLEs used by institutions as platforms for e-learning delivery permit each student to have a personal view of the courses they are enrolled in, many do not accommodate the social connectivity tools and personal profile spaces that students might choose, and that would assist them to integrate their experiences. Many CMSs and VLEs replicate traditional models of learning and teaching in online environments, conforming to a classroom or lecture hall metaphor, which may have a limiting effect on self directed and self regulated learning as tasks are pre-selected and resources are prescribed rather than negotiated (Hotrum, 2005; Lee, 2005; Sheely, 2006; Lane, 2008). Green, Facer, Rudd, Dillon and Humphreys (2005) summarise four key areas pivotal to enabling personalised learning through digital technologies. According to them, pedagogy must:

- ensure that learners are capable of making informed educational decisions;

- diversify and recognise different forms of skills and knowledge;

- create diverse learning environments; and

- include learner focused forms of feedback and assessment.

Linked to these principles is the concept of the PLE, defined by Siemens (2007b) as "a collection of tools, brought together under the conceptual notion of openness, interoperability and learner control. As such, PLEs are comprised of two elements the tools and the conceptual notions that drive how and why we select individual parts" (para. 2). Downes (2005) describes a learning environment as an approach, not an application, one that protects and celebrates identity, supports multiple levels of socialising, and encourages the development of communities of inquiry. He asserts that PLEs affirm the role of the individual in organising, customising and shaping his/her own learning environment. With PLEs, in contrast to the traditional approach whereby learning content is composed, organised and packaged, it is instead syndicated. From there, it is remixed and repurposed ('mashed up') with the student's own individual application in mind, the finished product being further syndicated to form inputs for other students' consumption and use, which may include further remixing, repurposing and redistribution. Rather than being an agreed upon concept, there are however, two quite different interpretations of PLEs. The first entails the understanding of personalisation as the need to embrace a learner centred but provider-driven approach to education; the second adopts the view of a wholly learner-driven approach that transcends the walls of any classroom, institution or organisation. The idea is for learners to exercise ownership and control over their experiences, rather than be constrained by centralised, instructor controlled learning based on the delivery of pre-packaged materials.

One exemplary approach of a provider-driven PLE can be seen in the work of Aviram, Ronen, Somekh, Winer and Sarid (2008), who describe the design and implementation of $i$ Class, an innovative "Self-Regulated Personalised Learning Environment" (SRPLE), as part of a project funded by the European Commission. iClass is intended to cater to individual learning needs by adapting education and learning in European societies to 
the challenges of the 21st century. The iClass system runs an Internet based platform and takes learners through three stages: planning, learning and reflection, with teachers acting as mentors at each stage. Aviram et al. oppose the rigid divides between structured learning and open, non-formal and incidental learning; between formal learning and solving authentic, real-life problems; between institutional (school, college, university) learning and lifelong learning; and between learning and human development generally. They posit that these issues have to be systematically addressed in the framework of revised pedagogical thinking that combines personalised learning with self regulated learning (hence self regulated personalised learning, or SRPL), empowering learners to actively define, create and shape their own learning content, tasks and hence their own learning trajectories. SRPL also includes the provision of adaptable and flexible learner and task scaffolding.

Both PLE models challenge university and college teachers to harness the many resources that exist outside the formal spaces of the institution, to create opportunities for authentic learning that is personally meaningful and relevant to learners, and to capitalise on the interests and digital competencies that learners already possess. PLEs stand in stark contrast to institutionally controlled, content-centric CMSs and VLEs as they provide learners with contextually-appropriate toolsets by enabling them to adjust, select, integrate and use various software, services and options based on their needs and circumstances. The result is, ideally, a model where learner needs, not technologies, drive the learning process (Attwell, 2006b, 2007). Nevertheless, both PLE models allow learners to make decisions about how to choose tools and configure the learning environment to best suit their learning goals and needs for networking, knowledge construction, social interaction and collaboration. In addition, both challenge traditional pedagogies where the teacher is the celebrated expert, dispensing knowledge and prescribing learning resources and activities.

\section{Rethinking pedagogy and the role of content}

Educators and institutions are increasingly beginning to recognise that the philosophy and ethos prevalent in the Web 2.0 world in which we live are highly incongruent with the control culture of education, where teacher-designed content and syllabi dominate. Today's world is characterised by social mobility and diversification of life trajectories, where individuals are expected to have multiple career paths and engage in reskilling at various stages throughout their lifespan. All of this signals a need to reconsider our notions of pedagogy so that learners are envisaged as active participants and coproducers of learning resources rather than passive consumers of content, and learning processes are participatory and social, supportive of personal life goals and needs (Brown \& Adler, 2008). There is a clear imperative for educators and students to move towards a social and participatory pedagogy rather than one based on the acquisition of pre-packaged facts. Siemens (2007a) is also critical of how institutions of higher learning operate and states that they "need to change because of the increasing complexity of society and globalization. Schools and universities play a dual role: accommodating learner's [sic] method and mode of learning and transforming learners and preparing them to function in the world that is unfolding" (para. 6, emphasis in original).

A further driver of change are the students themselves: their preferences, needs, social habits and technology choices. Along with the uptake of mobile devices and the rise of social media, tertiary student profiles indicate that a large proportion of students now 
juggle work and study, expect constant Internet connectivity and web based services, and view social networking tools as being central to their lives (Windham, 2005). Conole and Creanor (2007) report that students "have high expectations of how they should learn, selecting the technologies and learning environments that best meet their needs with a sophisticated understanding of how to manipulate these to their advantage" (p. 11). As Web 2.0 is participatory and collaborative, enabling connection globally with multiple social spheres, there is an increasing gap between the formalised interactions that occur in educational establishments and the modes of learning, socialisation and communication that youth experience and engage in. In particular, in the dominant tertiary education paradigm, students are presented with resources that have been created by teachers, instructional designers or developers, and are expected to demonstrate that they have absorbed the content therein through assessment tasks that rely on recall of information rather than on application, initiative or creative endeavour (Sener, 2007).

A number of authors (Hirshon, 2005; Boettcher, 2006) agree that there is a need to reevaluate the role of content in courses, and have advocated, for example, a greater focus on process (as opposed to product) and personal skill development. As the value of the traditional textbook is being questioned (Fink, 2005), the open educational resources (OER) movement is rapidly gaining momentum worldwide (Couros, 2006; Breck, 2007; Blackall, 2007; Brown \& Adler, 2008; Schaffert \& Geser, 2008; Keats, 2009) and e-learning content is becoming 'Napsterised' through peer-to-peer (P2P) file and media sharing services (Clark, 2003), we are witnessing a growth in emphasis on content that is produced by the learners themselves.

Sener (2007) contends that although student generated content has been a part of the education system for many decades, its role has been highly marginalised and its forms restricted to highly academic artefacts used exclusively for assessment purposes, such as essays and reports. In order to increase engagement, to promote self directed and self regulated learning as well as collaboration and knowledge sharing, and to encourage the development of products of value beyond the assessment or grading process, there is a need to expand our vision of educational content so that greater value is placed on student created products as a primary content source, In this way, students become active as both producers and consumers, or 'prosumers', of knowledge, ideas and artefacts.

In joining community of learning and practice that includes their classmates, teachers, past and future student cohorts, as well as others such as professionals and experts who may be external to the formal education environment, students not only must engage in "legitimate peripheral participation" (Lave \& Wenger, 1991) to develop their own mastery of knowledge and skills, but also have a responsibility to play a part in the continued advancement of the community's existing body of knowledge, as they move toward full participation in the socio-cultural practices of this community (Lee, Eustace, Hay \& Fellows, 2005). In such a knowledge-building community, members are managers, or 'curators' of the community's knowledge artefacts (Eustace \& Hay, 2000; Lee et al., 2005), intent on making responsible decisions in addition to generating novel and innovative contributions to benefit the community as a whole. 


\section{Designing personalised and self regulated learning tasks and environments: The need for scaffolding and some global examples}

In attempting to achieve learner self-regulation, the sole use of open ended or discovery learning environments in the absence of appropriate instructional support and task scaffolding has been criticised by a number of educational researchers (see, for example, Mayer, 2004). Moreover, though web based learning environments lend themselves to self regulated learning approaches (eg. inquiry based learning, problem based learning), new tasks and concepts impose numerous demands on learners (Narciss, Proske \& Koerndle, 2007). As a counterbalance, personalised, learner centred design offers a dynamic perspective that incorporates pedagogical scaffolds to support novice learners to learn and apply previously unknown thinking strategies, skills and practices (Aleven, Stahl, Schworm, Fischer \& Wallace, 2003). Scaffolding need not be teacher directed, and current social software tools can be used in ways that address learner centred concerns for self managed learning and control (for example, eportfolios). The challenge for educators, therefore, is to enable self direction, knowledge building and autonomy by providing options and choice while still supplying the necessary structure and scaffolding.

Internationally, there are a growing number of designs for tasks and learning environments that seek to achieve balance between self regulated and personalised learning and scaffolding support, while integrating Web 2.0 tools as well as the production, sharing and use of student-generated content. Table 1 below provides a number of examples, drawn from the exemplary practices of teachers at tertiary institutions across the globe.

\section{Discussion and implications for practice}

While the international examples in Table 1 provide good working models of self regulated and personalised learning, educators need to be equipped with principles and guidelines that can be applied in diverse contexts. How can the 'ideal' balance between scaffolded and learner-directed learning activities and tasks be achieved? What role should technologies, including but not limited to the ever-expanding and evolving raft of Web 2.0 and social computing tools, play in this process?

Jonassen (1994) maintains that the real challenge facing educational technologists is to consider instructional goals in a particular context, then to adjust the strategies, models and tactics as necessary to attune the nature of the task to the perspective of the student. Driver, Asoko, Leach, Mortimer and Scott (1994) are in concurrence with this view, adding that teachers have two roles: Firstly, a supportive role in introducing new ideas or cultural tools and supporting students in making sense of these for themselves, and secondly, a diagnostic role in continually examining students' interpretations of activities in order to help determine an appropriate direction for subsequent steps. Thus a major role of the teacher is arguably to facilitate this dynamic learning process, assisting learners in drawing their own links between their learning and the 'real world'; other roles may be that of 'consultant', 'guide' and 'resource provider' (Markel, 1999). 
Table 1: Global examples of how tertiary teachers enable self regulated and personalised learning using social software tools, while offering the necessary scaffolding/support

\begin{tabular}{|c|c|c|c|c|}
\hline $\begin{array}{l}\text { Institution } \\
\text { and } \\
\text { location }\end{array}$ & Reference & Context & $\begin{array}{l}\text { Self regulated learning } \\
\text { and scaffolding/ } \\
\text { support }\end{array}$ & Personalisation \\
\hline $\begin{array}{l}\text { Fashion } \\
\text { Institute of } \\
\text { Technol- } \\
\text { ogy, USA }\end{array}$ & $\begin{array}{l}\text { Harris } \\
(2007 a, \\
2007 b)\end{array}$ & $\begin{array}{l}\text { Students studying an } \\
\text { art history class visit } \\
\text { the Metropolitan } \\
\text { Museum of Art in } \\
\text { New York City, } \\
\text { where they take } \\
\text { photos of exhibits } \\
\text { using mobile phones, } \\
\text { upload them to Flickr, } \\
\text { and use the site's } \\
\text { tools to tag, annotate } \\
\text { and write descrip- } \\
\text { tions and comments } \\
\text { about the photos. }\end{array}$ & $\begin{array}{l}\text { Students engage in } \\
\text { learning tasks with a } \\
\text { high degree of auton- } \\
\text { omy and freedom, as } \\
\text { they mix and match } \\
\text { content and create } \\
\text { games and challenges } \\
\text { for one another. Task } \\
\text { scaffolding is provided } \\
\text { by the instructor by } \\
\text { using technology to } \\
\text { enable expression of } \\
\text { multiple perspectives } \\
\text { and by mediating peer } \\
\text { interaction. }\end{array}$ & $\begin{array}{l}\text { Personalisation and } \\
\text { customisation of tasks } \\
\text { ensures that students } \\
\text { remain motivated, i.e. } \\
\text { they have a personal } \\
\text { voice in making } \\
\text { commentaries and in } \\
\text { choosing descriptors to } \\
\text { tag the photos. Peer to } \\
\text { peer content sharing } \\
\text { adds a collaborative } \\
\text { dimension while still } \\
\text { allowing individual } \\
\text { reflection and } \\
\text { achievement. }\end{array}$ \\
\hline $\begin{array}{l}\text { Victoria } \\
\text { University } \\
\text { of } \\
\text { Wellington } \\
\text { New } \\
\text { Zealand }\end{array}$ & $\begin{array}{l}\text { Elgort, } \\
\text { Smith \& } \\
\text { Toland } \\
(2008)\end{array}$ & $\begin{array}{l}\text { A mixture of on } \\
\text { campus and distance } \\
\text { education students } \\
\text { enrolled in a Master } \\
\text { of Library and } \\
\text { Information Studies } \\
\text { (MLIS) program work } \\
\text { in groups to } \\
\text { collaboratively } \\
\text { produce web based } \\
\text { information resource } \\
\text { guides using a wiki. }\end{array}$ & $\begin{array}{l}\text { The groups work aut- } \\
\text { onomously to produce } \\
\text { three deliverables based } \\
\text { on instructor supplied } \\
\text { guidelines: the resource } \\
\text { guide (a web site provi- } \\
\text { ding links to / evalua- } \\
\text { tions of information res- } \\
\text { ources); presentation of } \\
\text { the completed guide to } \\
\text { the class; and an online } \\
\text { journal in which stud- } \\
\text { ents document their } \\
\text { work processes and } \\
\text { reflect on their personal } \\
\text { contributions. }\end{array}$ & $\begin{array}{l}\text { Each group of students } \\
\text { chooses a topic that is } \\
\text { personally meaningful, } \\
\text { relevant and / or } \\
\text { interesting to its } \\
\text { members. The students } \\
\text { also have flexibility in } \\
\text { terms of their ability to } \\
\text { personalise the content } \\
\text { and the way it is } \\
\text { presented using a range } \\
\text { of digital media types. }\end{array}$ \\
\hline $\begin{array}{l}\text { Bentley } \\
\text { College } \\
\text { (now } \\
\text { Bentley } \\
\text { University) } \\
\text { USA }\end{array}$ & $\begin{array}{l}\text { Fryden- } \\
\text { berg (2006) }\end{array}$ & $\begin{array}{l}\text { Students studying an } \\
\text { information technol- } \\
\text { ogy (IT) fundamentals } \\
\text { course purchase } \\
\text { Pocket PCs instead of } \\
\text { textbooks, which they } \\
\text { use to explore IT con- } \\
\text { cepts in a hands on, } \\
\text { learner centred appr- } \\
\text { oach. They form pairs } \\
\text { or groups and work } \\
\text { together to plan and } \\
\text { produce vodcasts } \\
\text { (video podcasts). Each } \\
\text { pair/group produces } \\
\text { a vodcast based } \\
\text { around a topic in the } \\
\text { course schedule, for } \\
\text { sharing with the rest } \\
\text { of the class (via a }\end{array}$ & $\begin{array}{l}\text { Each pair group has to } \\
\text { work largely independ- } \\
\text { ently, with each } \\
\text { member managing and } \\
\text { regulating his/her own } \\
\text { learning while also } \\
\text { contributing to the } \\
\text { overall management / } \\
\text { coordination and } \\
\text { direction of the group. } \\
\text { The instructor makes } \\
\text { available a number of } \\
\text { sample 'exemplary' } \\
\text { vodcasts (a form of } \\
\text { modelling) and } \\
\text { provides scaffolding in } \\
\text { relation to the technical } \\
\text { aspects of the assign- } \\
\text { ment, eg. instruction on } \\
\text { video recording and }\end{array}$ & $\begin{array}{l}\text { In addition to being able } \\
\text { to select topics of } \\
\text { personal interest } \\
\text { and/or significance for } \\
\text { presentation to their } \\
\text { peers, the students can } \\
\text { consume the content at } \\
\text { times and places of their } \\
\text { choosing, using a range } \\
\text { of devices (including } \\
\text { mobile/portable } \\
\text { devices) that } \\
\text { incorporate vodcast } \\
\text { playback capabilities. }\end{array}$ \\
\hline
\end{tabular}




\begin{tabular}{|c|c|c|c|c|}
\hline & & $\begin{array}{l}\text { Really Simple } \\
\text { Syndication or RSS } \\
\text { feed), as a form of } \\
\text { peer or reciprocal } \\
\text { teaching. }\end{array}$ & $\begin{array}{l}\text { editing techniques, and } \\
\text { the setup of the RSS } \\
\text { feed as a distribution } \\
\text { mechanism for the } \\
\text { vodcasts. }\end{array}$ & \\
\hline $\begin{array}{l}\text { The Open } \\
\text { University } \\
\text { of Hong } \\
\text { Kong, } \\
\text { China }\end{array}$ & $\begin{array}{l}\text { Lui, Choy, } \\
\text { Cheung \& } \\
\text { Li (2006) }\end{array}$ & $\begin{array}{l}\text { Students studying a } \\
\text { year-long Software } \\
\text { Engineering and } \\
\text { Project Management } \\
\text { course are required to } \\
\text { write reflective blog } \\
\text { entries in response to } \\
\text { stimulus questions. } \\
\text { The blog sites are } \\
\text { used both as } \\
\text { knowledge sharing } \\
\text { and personal work / } \\
\text { information spaces. }\end{array}$ & $\begin{array}{l}\text { Learners are free to ex- } \\
\text { press ideas and engage } \\
\text { in reflective processes } \\
\text { on an individual basis, } \\
\text { combining both indep- } \\
\text { endent work and peer } \\
\text { feedback, thus ensuring } \\
\text { independent learning } \\
\text { and collaborative inter- } \\
\text { action. Scaffolds take } \\
\text { the form of structured } \\
\text { tasks plus formative } \\
\text { peer and tutor } \\
\text { evaluation. }\end{array}$ & $\begin{array}{l}\text { Students work at their } \\
\text { own pace and express } \\
\text { ideas in their own style } \\
\text { through blogs and } \\
\text { wikis. The creation of e- } \\
\text { portfolios also } \\
\text { documents each } \\
\text { student's personal } \\
\text { learning achievement } \\
\text { and thereby supports } \\
\text { personalisation. }\end{array}$ \\
\hline $\begin{array}{l}\text { University } \\
\text { of } \\
\text { Leicester, } \\
\text { UK }\end{array}$ & $\begin{array}{l}\text { Edirising- } \\
\text { ha, Salmon } \\
\text { \& Forther- } \\
\text { gill (2006, } \\
\text { 2007) }\end{array}$ & $\begin{array}{l}\text { Second- and third- } \\
\text { year undergraduate } \\
\text { engineering students } \\
\text { make use of } \\
\text { 'profcasts', i.e. } \\
\text { material designed to } \\
\text { support learning } \\
\text { distinct from that } \\
\text { which is facilitated } \\
\text { through structured } \\
\text { on-campus or e- } \\
\text { learning processes } \\
\text { alone. }\end{array}$ & $\begin{array}{l}\text { Students learn indepen- } \\
\text { dently by choosing } \\
\text { profcasts that are relev- } \\
\text { ant to their needs. Scaff- } \\
\text { olds include resources } \\
\text { created by the instruc- } \\
\text { tor, and contexts where } \\
\text { students can apply new } \\
\text { knowledge. Weekly } \\
\text { profcasts are released to } \\
\text { supplement online } \\
\text { teaching through upda- } \\
\text { ted information and } \\
\text { guidance on the assign- } \\
\text { ed activities for the } \\
\text { week, and to motivate } \\
\text { students through the } \\
\text { incorporation of relev- } \\
\text { ant news items, anec- } \\
\text { dotes and jokes. A } \\
\text { framework based on } \\
\text { Salmon's (2002) e- } \\
\text { tivities model is used to } \\
\text { foster active learning. }\end{array}$ & $\begin{array}{l}\text { The learning content is } \\
\text { personalised by } \\
\text { enabling students to } \\
\text { choose when, where } \\
\text { and how to make use of } \\
\text { the enrichment } \\
\text { resources and } \\
\text { undertake the extended } \\
\text { learning activities. }\end{array}$ \\
\hline $\begin{array}{l}\text { The Open } \\
\text { University, } \\
\text { UK }\end{array}$ & $\begin{array}{l}\text { Kukulska- } \\
\text { Hulme } \\
(2005)\end{array}$ & $\begin{array}{l}\text { Students attending } \\
\text { German and Spanish } \\
\text { summer schools use } \\
\text { digital voice recorders } \\
\text { and mini-camcorders } \\
\text { to record interviews } \\
\text { with other students } \\
\text { and with native spea- } \\
\text { kers of the languages } \\
\text { they are studying, as } \\
\text { well as to create } \\
\text { audio-visual tours for } \\
\text { sharing with their } \\
\text { peers via the Internet. }\end{array}$ & $\begin{array}{l}\text { Students engage in self } \\
\text { regulated learning as } \\
\text { they develop, share and } \\
\text { reflect on learner gener- } \\
\text { ated content. The instr- } \\
\text { uctors supply the rec- } \\
\text { ording equipment and } \\
\text { provide guidance to the } \\
\text { students in completing } \\
\text { the various activities, } \\
\text { eg. by providing } \\
\text { sample topics / } \\
\text { questions for the } \\
\text { student-led interviews. }\end{array}$ & $\begin{array}{l}\text { Learners create } \\
\text { authentic content and } \\
\text { tasks for peers that are } \\
\text { personally meaningful } \\
\text { and relevant, and are } \\
\text { able to exercise a large } \\
\text { amount of choice as } \\
\text { they work with multiple } \\
\text { modalities, tools and } \\
\text { media in various forms } \\
\text { (text, voice, pictures, } \\
\text { etc). }\end{array}$ \\
\hline
\end{tabular}




\begin{tabular}{|c|c|c|c|c|}
\hline $\begin{array}{l}\text { Queens- } \\
\text { land } \\
\text { University } \\
\text { of Technol- } \\
\text { ogy, } \\
\text { Australia }\end{array}$ & $\begin{array}{l}\text { English \& } \\
\text { Duncan- } \\
\text { Howell } \\
(2008)\end{array}$ & $\begin{array}{l}\text { Pre-service teacher } \\
\text { education students } \\
\text { use the social } \\
\text { networking tool } \\
\text { Facebook during their } \\
\text { teaching practicum } \\
\text { placements to } \\
\text { facilitate mutual } \\
\text { support, encourag- } \\
\text { ement and the sharing } \\
\text { of stories/anecdotes. }\end{array}$ & $\begin{array}{l}\text { Self directed learning is } \\
\text { encouraged by enabling } \\
\text { students to create, share } \\
\text { and comment on } \\
\text { others' contributions, } \\
\text { and by allowing them } \\
\text { to choose from multiple } \\
\text { forms of support. } \\
\text { Scaffolding is provided } \\
\text { by peers as they guide } \\
\text { and assist one another, } \\
\text { sharing digital artefacts } \\
\text { and exchanging } \\
\text { constructive feedback. }\end{array}$ & $\begin{array}{l}\text { Personal choices are } \\
\text { exercised by } \\
\text { encouraging expression } \\
\text { of and reflection on } \\
\text { individual learning } \\
\text { journeys. }\end{array}$ \\
\hline $\begin{array}{l}\text { Charles } \\
\text { Sturt } \\
\text { University, } \\
\text { Australia }\end{array}$ & \begin{tabular}{|l|} 
Peacock, \\
Fellows \& \\
Eustace \\
(2007); Lee, \\
Eustace, \\
Hay \& \\
Fellows \\
$(2005)$
\end{tabular} & $\begin{array}{l}\text { Students undertaking } \\
\text { an online course on } \\
\text { computer-supported } \\
\text { collaborative work } \\
\text { (CSCW) learn with } \\
\text { and about collab- } \\
\text { orative groupware } \\
\text { tools and information } \\
\text { environments, incl- } \\
\text { uding a range of Web } \\
1.0 \text { and } 2.0 \text { technol- } \\
\text { ogies. The students } \\
\text { form groups of three } \\
\text { or four students } \\
\text { called 'PODs' (Pools } \\
\text { of Online Dialogue), } \\
\text { and each group is } \\
\text { given a fortnight to } \\
\text { complete each of four } \\
\text { collaborative } \\
\text { activities / exercises. }\end{array}$ & $\begin{array}{l}\text { Through distributed, } \\
\text { collaborative learning } \\
\text { processes supported by } \\
\text { social software tools, } \\
\text { students engage in both } \\
\text { 'top down' (teacher dir- } \\
\text { ected) and 'bottom up' } \\
\text { (learner directed) activ- } \\
\text { ities that enable high } \\
\text { levels of freedom and } \\
\text { empowerment. The } \\
\text { instructors assist with } \\
\text { the setup of the technol- } \\
\text { ogy and develop guide- } \\
\text { lines for the fortnightly } \\
\text { group tasks, including } \\
\text { stimulus questions to } \\
\text { promote reflection and } \\
\text { discussion. Instructors } \\
\text { participate in PODs as } \\
\text { 'guests' only when } \\
\text { invited to do so. }\end{array}$ & $\begin{array}{l}\text { The POD activities are } \\
\text { not graded directly; } \\
\text { instead, students incor- } \\
\text { porate evidence of com- } \\
\text { pleting the activities, } \\
\text { together with reflective } \\
\text { comments on their indi- } \\
\text { vidual experiences, into } \\
\text { their personal e-port- } \\
\text { folios, assessed at the } \\
\text { end of the course along } \\
\text { with other multimedia } \\
\text { learning produced or } \\
\text { captured during the } \\
\text { semester. Each fort- } \\
\text { night, students are } \\
\text { required to contribute } \\
500 \text { words to the class } \\
\text { wiki; these words can } \\
\text { be 'spent' creating a } \\
\text { new article, adding to } \\
\text { an existing article, or } \\
\text { pooled with other } \\
\text { people to generate a } \\
\text { larger article. }\end{array}$ \\
\hline
\end{tabular}

Educational/instructional technologies, then, may best be used to furnish support and assist in scaffolding learning and reflection within the authentic or real world contexts in which knowledge construction naturally occurs, as well as serving as means by which learners can capture evidence of their authentic performances in situ within these contexts, for assessment, evaluation and feedback purposes (see also Hai-Jew, 2008). A number of researchers have already begun to propose various tools, techniques and approaches to support the active involvement of both teachers and students in the design of learning tasks and environments (see, for example, Ronteltap, Goodyear \& Bartoluzzi, 2004; Goodyear, de Laat \& Lally, 2006; McAndrew, Goodyear \& Dalziel, 2006); new instructional and learning design practices are emerging that are based on the idea of student ownership of tasks, and that emphasise the importance of allowing flexibility, encouraging self direction and choice as well as promoting creativity in the performance of tasks. 
Moving towards the personalisation of learning environments also entails aiding learners in developing the fundamental skills that enable them to manage their own learning. The 2009 Horizon report (New Media Consortium, 2009) stresses that a critical challenge is to design learning experiences that scaffold the development of key competencies, including visual, technological and information literacy and the 'soft' skills of communication and teamwork. In the digital age, the range of scaffolds is varied and complex, and the learner must play an active role in negotiating the type of contextual, social and task support needed. The meaning of scaffolding is no longer confined to its original association of expertise provided by a knowledgeable other (Wood, Bruner \& Ross, 1976), but has expanded to include learner selected assistance, peer interactions, or could be embedded in technology.

The above having been said, despite the abundance of good practice examples there continue to be significant gaps in teachers' espoused and enacted learner-centred pedagogies. In the Web 2.0 era, the need to close these gaps to achieve truly student centred learning is paramount, as learners, more so than ever before, desire and demand high degrees of autonomy, connectivity and socio-experiential learning (McLoughlin \& Lee, 2008). Fortunately, Web 2.0 also equips educators with a rich repertoire of services and applications to address this challenge by enabling learner choice and allowing creative decisions about how to best to set learning goals and create learning environments that support those goals. The essential difference in the role of the institution is a move from delivery of content to a focus on designing experiences to facilitate personal learning, capability building and skills development, combined with a renewed emphasis on curriculum design that values the student's voice and needs in shaping decision making.

\section{Conclusion}

In this article, we have argued for personalised learning spaces, resources and environments to be developed, supported and created through systematic design as well as by inclusion of both instructor and learner perspectives, as well as for the integration of Web 2.0 tools and strategies. As online or Internet based learning is now the mode of learning for many students globally, there is an often an expectation that students commence university study with reasonably high levels of digital skills to enable them to negotiate, interact and access resources independently (Lorenzo \& Dziuban, 2006; Katz \& Macklin, 2007). Also, as noted in many recent reports, the dispositions developed through engagement with Web 2.0 and social software technologies - i.e. communication skills, participation, networking, sharing - overlap with what are viewed as essential 21st-century learning and employability skills (Punie, Cabrera, Bogdanowicz, Zinnbauer \& Navajas, 2006; Jenkins, 2007; CLEX, 2009).

Nonetheless we have made a case for stronger and more explicit scaffolding of essential skills and digital literacies as students may not have advanced knowledge of how to use the technology for academic purposes, and may not see the relevance of social media for learning. In fact, their day to day use of ICTs may have cultivated in them impatience and a desire for instant answers (Center for Generational Studies, 2007; Tynan, Lee \& Barnes, 2008), as well as leading them to take a casual approach to critical evaluation, plagiarism and information ownership (CLEX, 2009). For higher education institutions in many countries, the development of digital literacies and independent learning is now high on the agenda. Universities and colleges are being advised to implement both the infrastructure and the curriculum changes to maximise 
the potential of the new tools to support learning by capitalising on the competencies and skills students bring into the classroom, while at the same time helping them obtain the attributes and capabilities to prepare them for work and life in the digital economy and networked society (see Brown \& Adler, 2008; Kennedy et al. 2009).

The challenges for educators are complex and multifaceted, and include the provision of personalised learning experiences using suitable technologies that cultivate independent learning skills, while also scaffolding learner reflection and the development of generic competencies. The pedagogical change that is required involves not only the espousal of appropriate teaching approaches, but also awareness of the learner experience, and the importance of valuing learners' pre-existing skills and capitalising on them, while exploring and integrating social media in ways that pave the way for participation, community connections, social interaction and global networking. At the same time, teachers who adopt social software tools should not do so merely to appear conversant with the tools, but to ensure integration of the tools with sound pedagogical strategies so as to facilitate authentic exchange and dialogue with and amongst students. They must be wary of potential privacy issues involved in the use of Web 2.0 tools for teaching, learning and assessment, not to mention the fact that they may feel unwelcome in their students' online social networks and communities. Although there may be attempts by teachers to co-opt the technologies students use for communication and entertainment, such attempts may be perceived by students as intrusions into "their space" (Mazer, Murphy \& Simonds, 2007).

All in all, addressing the need to rethink and reposition pedagogy for the new learning landscape of the 21st century calls for the active involvement of students in defining their learning goals and choosing both ICT tools and strategies for learning; it also requires recognition that user and learner generated content has a central place in a curriculum that fosters self regulated learning. There is a fine balance to be achieved in attempting to promote learner control, knowledge creation, agency and autonomy by offering flexible options and choice, whilst offering guidance and structure when needed and adding value to the learning process through personalised, customised and adaptive approaches.

\section{References}

Aleven, V., Stahl, E., Schworm, S., Fischer, F. \& Wallace, R.M. (2003). Help seeking and help design in interactive learning environments. Review of Educational Research, 73(3), 277-320. [verified 14 Jan 2010] https:// www.msu.edu/ mccrory/pubs/Alevenetal.pdf

Ashton, J. \& Newman, L. (2006). An unfinished symphony: 21st century teacher education using knowledge-creating heutagogies. British Journal of Educational Technology, 37(6), 825-84.

Attwell, G. (2006a). Personal Learning Environments. The Wales-Wide Web [weblog], 1 Jun. [viewed 9 Jun 2009]. http:/ / www.knownet.com/writing/weblogs/Graham_Attwell/ entries / 6521819364

Attwell, G. (2006b). Why Personal Learning Environments are important. The Wales-Wide Web [weblog], 20 Jan. [viewed 9 Jun 2009, verified 14 Jan 2010]. http: / / www.knownet.com/writing/weblogs/Graham_Attwell/entries / 8463960484

Attwell, G. (2007). Personal Learning Environments - the future of eLearning? eLearning Papers, 2. http:/ / www.elearningeuropa.info/out / ?doc_id=9758\&rsr_id=11561

Aviram, A., Ronen, Y., Somekh, S., Winer, A. \& Sarid, A. (2008). Self-regulated personalised learning (SRPL): Developing iClass's pedagogical model. eLearning Papers, 9. http: / / www.elearningpapers.eu / index.php?page=doc\&doc_id=11941\&doclng=6 
Biggs, J. (1987). Student approaches to learning and studying. Hawthorne, Vic.: ACER.

Blackall, L. (2007). Open educational resources and practices. Journal of e-Learning and Knowledge Society, 3(2), 63-81. http: / / www.je-lks.it/en/07_02/06Art_blackall_inglese.pdf

Boettcher, J. V. (2006). The rise of student performance content. Campus Technology, 28 Feb. [verified 17 Jan 2010] http:/ / www.campustechnology / article.aspx?aid=40747

Breck, J. (Ed.) (2007). Opening educational resources [Special issue]. Educational Technology, 47(6). [verified 17 Jan 2010] http:/ / asianvu.com/bookstoread/etp/Educational_Technology_NovDec2007_issue.pdf

Brown, J.S. \& Adler, R.P. (2008). Minds on fire: Open education, the long tail, and Learning 2.0. EDUCAUSE Review, 43(1), 16-32. http:/ / net.educause.edu/ir/library/pdf/ERM0811.pdf

Bryant, L. (2007). Emerging trends in social software for education. In Emerging technologies for learning (Vol. 2, pp. 10-18). Coventry, UK: Becta. [viewed 17 Oct 2007]. http:/ / partners.becta.org.uk/page_documents/research/emerging_technologies07_chapter1.pdf

Center for Generational Studies (2007). Did you ever wonder? Frequently asked questions about generational differences. [viewed 17 Oct 2007, verified 17 Jan 2010]. http: / / www.gentrends.com/ faq.html

Clark, D. (2003). The Napsterisation of learning (P2P). Brighton, UK: Epic Group.

CLEX (2009). Higher education in a Web 2.0 world: Report of an independent Committee of Inquiry into the impact on higher education of students' widespread use of Web 2.0 technologies. [viewed 20 Aug 2009]. Bristol, UK: CLEX. http: / / clex.org.uk/CLEX_Report_v1-final.pdf

Conole, G. \& Creanor, L. (2007). In their own words: Exploring the learner's perspective on e-learning. London: JISC. [viewed 17 Oct 2009].

http: / / www.jisc.ac.uk/media/ documents / programmes / elearningpedagogy/iowfinal.pdf

Couros, A.V. (2006). Examining the open movement: Possibilities and implications for education. Unpublished doctoral dissertation, University of Regina, Regina, SK, Canada. [verified 17 Jan 2010] http:/ / www.scribd.com/doc/3363/Dissertation-Couros-FINAL-06WebVersion?autodown $=$ pdf

Downes, S. (2005). E-learning 2.0. eLearn Magazine, Oct. http: / / www.elearnmag.org/ subpage.cfm?section=articles\&article=29-1

Driver, R., Asoko, H., Leach, J., Mortimer, E. \& Scott, P. (1994). Constructing scientific knowledge in the classroom. Educational Researcher, 23(7), 5-12.

Dron, J. (2007). Designing the undesignable: Social software and control. Educational Technology E Society, 10(3), 60-71. http:/ / www.ifets.info/journals/10_3/5.pdf

Edirisingha, P., Salmon, G. \& Fothergill, J. (2006). Enriching a blended learning environment with podcasts and e-tivities: A case study. Paper presented at the First International Blended Learning Conference: Promoting dialogue in innovation and practice, Hatfield, UK, 15 Jun. [verified 17 Jan 2010] http:/ / www.herts.ac.uk/ fms / documents/teaching-andlearning/blu/Palitha\%20Edirisingha\%202006.pdf

Edirisingha, P., Salmon, G. \& Fothergill, J. (2007). Profcasting - a pilot study and guidelines for integrating podcasts in a blended learning environment. In U. Bernath \& A. Sangrà (Eds), Research on competence development in online distance education and e-learning: Selected papers from the 4th EDEN Research Workshop in Castelldefels/Spain, 25-28 October 2006 (pp. 127-37). Oldenberg, Germany: BIS-Verlag der Carl von Ossietzky Universität Oldenburg.[verified 17 Jan 2010] http: / / hdi.handle.net/2381/ 404

Elgort, I., Smith, A .G. \& Toland, J. (2008). Is wiki an effective platform for group course work? Australasian Journal of Educational Technology, 24(2), 195-210. http: / / www.ascilite.org.au/ajet/ajet24/elgort.html 
English, R. \& Duncan-Howell, J. (2008). Facebook goes to college: Using social networking tools to support students undertaking teaching practicum. Journal of Online Learning and Teaching, 4(4), 596-601. http: / / jolt.merlot.org/vol4no4/english_1208.pdf

Eustace, K. \& Hay, L. (2000). A community and knowledge building model in computer education. In A. E. Ellis (Ed.), Proceedings of the Australasian Conference on Computing Education (pp. 95-102). New York: Association for Computing Machinery.

Fink, L. (2005). Making textbooks worthwhile. Chronicle of Higher Education, 16 Sep. http: / / chronicle.com/weekly/v52/i04/04b01201.htm

Fitzgerald, R. \& Steele, J. (2008). Digital Learning Communities (DLC): Investigating the application of social software to support networked learning (CG6-36). Sydney: Australian Learning and Teaching Council. [viewed 17 Oct 2009].

http: / / www.altc.edu.au/system/files / resources/grants_cg_report_dlc_uc_feb09.pdf

Frydenberg, M. (2006). Principles and pedagogy: The two $\mathrm{P}^{\prime} \mathrm{s}$ of podcasting in the information technology classroom. In D. Colton, W. J. Tastle, M. Hensel \& A. A. Abdullat (Eds), Proceedings of ISECON 2006 (\$3354). Chicago: Association of Information Technology Professionals. http:/ / proc.isecon.org/2006/3354/ ISECON.2006.Frydenberg.pdf

Goodyear, P., de Laat, M. \& Lally, V. (2006). Using pattern languages to mediate theory-praxis conversations in design for networked learning. ALT-J Research in Learning Technology, 14(3), 211-223. http: / / repository.alt.ac.uk/120/

Green, H., Facer, K., Rudd, T., Dillon, P. \& Humphreys, P. (2005). Personalisation and digital technologies. Bristol: Futurelab. [viewed 17 Oct 2009] http:/ / www.futurelab.org.uk/ resources/documents/opening_education/Personalisation_report.pdf

Hai-Jew, S. (2008). Scaffolding discovery learning spaces. MERLOT Journal of Online Learning and Teaching, 4(4), 533-548. http:/ / jolt.merlot.org/vol4no4/hai-jew_1208.pdf

Harris, B. (2007a). Flickr in art history class - how fun! smARThistory [weblog], 25 Oct. http: / / smarthistory.org/blog/88/ flickr-in-art-history-class-how-fun/ [viewed 13 Jun 2009, verified 20 Jan 2010]

Harris, B. (2007b). Midterm. Art Survey: HA 112 at FIT. http: / / smarthistory.org/artsurvey/?page_id=13 [viewed 13 Jun 2009; not found 20 Jan 2010]

Hirshon, A. (2005). A diamond in the rough: Divining the future of e-content. EDUCAUSE Review, 40(1), 34-44. http: / / www.educause.edu/ir/library/pdf/ERM0512.pdf

Hotrum, M. (2005). Breaking down the LMS walls. The International Review of Research in Open and Distance Learning, 6(1). http: / / www.irrodl.org/index.php/irrodl/article/view / 212/295

Jenkins, H. (2007). Confronting the challenges of participatory culture: Media education for the 21st Century. Chicago: MacArthur Foundation. http: / / www.digitallearning.macfound.org/atf / cf /\%7B7E45C7E0-A3E0-4B89-AC9CE807E1B0AE4E\%7D/JENKINS_WHITE_PAPER.PDF [viewed 17 Oct 2009]

Jonassen, D. H. (1994). Thinking technology: Towards a constructivist design model. Educational Technology, 34(4), 34-37.

Katz, I. R. \& Macklin, A .S. (2007). Information and communication technology (ICT) literacy: Integration and assessment in higher education. Systemics, Cybernetics and Informatics, 5(4), $50-55$.

Keats, D. (2009). The road to Free and Open Educational Resources at the University of the Western Cape: A personal and institutional journey. Open Learning, 24(1), 47-55. 
Kennedy, G., Dalgarno, B., Bennett, S., Gray, K., Judd, T., Waycott, J., Chang, R., Bishop, A., Maton, K. \& Krause, K.-L. (2009). Educating the Net Generation: Implications for learning and teaching in Australian universities. Final report. Sydney: Australian Learning and Teaching Council. [viewed 14 Aug 2009] http: / / www.altc.edu.au/system/ files / resources/CG625_Melbourne_Kennedy_Final\%20Report_July09_v2.pdf

Kukulska-Hulme, A. (2005). The mobile language learner - now and in the future [webcast]. Plenary session delivered at the Fran Vision till Praktik (From Vision to Practice) Language Learning Symposium, Umeå, Sweden, 11-12 May. [viewed 17 Oct 2009] http:// www2.humlab.umu.se/video/Praktikvision/agnes.ram

Lane, L .M. (2008). Toolbox or trap? Course management systems and pedagogy. EDUCAUSE Quarterly, 31(2), 4-6. http:/ / www.educause.edu/ir/library/pdf/EQM0820.pdf

Lave, J. \& Wenger, E. (1991). Situated learning: Legitimate peripheral participation. Cambridge, UK: Cambridge University Press.

Lee, M. J. W. (2005). New tools for online collaboration: Blogs, wikis, RSS and podcasting. Training and Development in Australia, 32(5), 17-20.

Lee, M. J. W., Eustace, K., Hay, L. \& Fellows, G. (2005). Learning to collaborate, collaboratively: An online community building and knowledge construction approach to teaching computer supported collaborative work at an Australian university. In M. R. Simonson \& M. Crawford (Eds), Proceedings of the 2005 AECT International Convention (pp. 286-306). North Miami Beach, FL: Nova Southeastern University.

Lee, M. J. W., McLoughlin, C. \& Chan, A. (2008). Talk the talk: Learner-generated podcasts as catalysts for knowledge creation. British Journal of Educational Technology, 39(3), 501-521.

Lorenzo, G. \& Dziuban, C. (2006). Ensuring the Net Generation is net savoy. Washington, DC: EDUCAUSE. [viewed 18 Jul 2009] http: / / www.educause.edu/ir/library/pdf/ELI3006.pdf

Lui, A. K., Choy, S.-O., Cheung, Y. H. Y. \& Li, S. C. (2006). A study on the perception of students towards educational weblogs. Informatics in Education, 5(2), 233-254.

Markel, M. (1999). Distance education and the myth of the new pedagogy. Journal of Business and Technical Communication, 13(2), 208-223.

Mayer, R.E. (2004). Should there be a three-strikes rule against pure discovery learning? The case for guided methods of instruction. American Psychologist, 59(1), 14-19.

Mazer, J .P., Murphy, R. E. \& Simonds, C. J. (2007). I'll see you on “Facebook": The effects of computer-mediated teacher self disclosure on student motivation, affective learning, and classroom climate. Communication Education, 56(1), 1-17.

McAndrew, P., Goodyear, P. \& Dalziel, J. (2006). Patterns, designs and activities: Unifying descriptions of learning structures. International Journal of Learning Technology, 2(2), 216-242. [verified 20 Jan 2010] http: / / wiki.lamsfoundation.org/download/attachments / 9469955/goodyear_patterns.pdf

McLoughlin, C. \& Lee, M. J. W. (2008). Future learning landscapes: Transforming pedagogy through social software. Innovate: Journal of Online Education, 4(5). http: / / innovateonline.info / ?view=article\&id=539

Minocha, S. (2009). A study on the effective use of social software by further and higher education in the UK to support student learning and engagement. Bristol: JISC.

http: / / www.jisc.ac.uk/media/ documents/ projects/effective-use-of-social-software-ineducation-finalreport.pdf [viewed 14 Aug 2009]. 
Narciss, S., Proske, A. \& Koerndle, H. (2007). Promoting self-regulated learning in web-based environments. Computers in Human Behavior, 23(3), 1126-1144.

New Media Consortium (2006). The Horizon report: 2006 edition. Austin, TX: NMC. http:/ / www.nmc.org/pdf/2006_Horizon_Report.pdf [viewed 4 Aug 2009].

New Media Consortium (2007). The Horizon report: 2007 edition. Austin, TX: NMC. http:/ / www.nmc.org/pdf/2007_Horizon_Report.pdf [viewed 4 Aug 2009].

New Media Consortium (2008). The Horizon report: 2008 edition. Austin, TX: NMC. http:/ / www.nmc.org/pdf/2008-Horizon-Report.pdf [viewed 4 Aug 2009].

New Media Consortium (2009). The Horizon report: 2009 edition. Austin, TX: NMC. http:/ / www.nmc.org/pdf/2009-Horizon-Report.pdf [viewed 4 Aug 2009].

Owen, M., Grant, L., Sayers, S. \& Facer, K. (2006). Social software and learning. Bristol, UK: Futurelab. [viewed 17 Oct 2009]. http: / / www.futurelab.org.uk/ resources / documents/opening_education/Social_Software_report.pdf

Peacock, T., Fellows, G. \& Eustace, K. (2007). The quality and trust of wiki content in a learning community. In ICT: Providing choices for learners and learning. Proceedings ascilite Singapore 2007. http:/ / www.ascilite.org.au/conferences/singapore07/procs/ peacock.pdf

Punie, Y., Cabrera, M., Bogdanowicz, M., Zinnbauer, D. \& Navajas, E. (2006). The future of ICT and learning in the knowledge society: Report on a joint DG JRC-DG EAC workshop held in Seville, 20-21 October 2005. Luxembourg: European Communities. http: / / ftp.jrc.es/EURdoc/eur22218en.pdf [viewed 17 Oct 2009].

Ronteltap, F., Goodyear, P. \& Bartoluzzi, S. (2004). A pattern language as an instrument in designing for productive learning conversations. In L. Cantoni \& C. McLoughlin (Eds), Proceedings of World Conference on Educational Multimedia, Hypermedia and Telecommunications 2004 (pp. 4271-4276). Chesapeake, VA: Association for the Advancement of Computers in Education.

Salaway, G., Caruso, J.B. \& Nelson, M.R. (2008). The ECAR study of undergraduate students and information technology, 2008. Boulder, CO: EDUCAUSE Center for Applied Research. [viewed 16 Oct 2009]. http:/ / www.educause.edu/ir/library/pdf/ERS0808/RS/ERS0808w.pdf

Salmon, G. (2002). E-tivities: The key to active online learning. London: Kogan Page.

Schaffert, S. \& Geser, G. (2008). Open educational resources and practices. eLearning Papers, 8. [verified 20 Jan 2010] http:/ / www.elearningeuropa.info/files/media/media14907.pdf

Sener, J. (2007). In search of student-generated content in online education. e-mentor, 21. http: / / www.e-mentor.edu.pl/_xml/wydania/21/467.pdf

Sheely, S. (2006). Persistent technologies: Why can't we stop lecturing online? In Who's learning? Whose technology? Proceedings ascilite Sydney 2006. Sydney: University of Sydney. http: / / www.ascilite.org.au/conferences/sydney06/proceeding/pdf_papers/p167.pdf

Siemens, G. (2007a). Digital natives and immigrants: A concept beyond its best before date. Connectivism blog [weblog], Oct. [viewed 4 Nov 2007].

http: / / connectivism.ca/blog/2007/10/digital_natives_and_immigrants.html

Siemens, G. (2007b). PLEs - I acronym, therefore I exist. elearnspace: learning, networks, knowledge, technology, community [weblog], 15 Apr. [viewed 13 Jun 2009]. http: / / www.elearnspace.org/blog/archives / 002884.html

Simons, P. R.-J. (1992). Constructive learning: The role of the learner. In T.M. Duffy, J. Lowyck, D. Jonassen \& T.M. Welsh (Eds), Designing environments for constructive learning (pp. 291-313). Berlin: Springer-Verlag. 
Stubbé, H.E. \& Theunissen, N.C.M. (2008). Self-directed adult learning in a ubiquitous learning environment: A meta-review. In M. Kalz, R. Koper, V. Hornung-Prähauser \& M. Luckmann (Eds), Proceedings of the First Workshop on Technology Support for Self-Organized Learners (pp. 528). Aachen, Germany: RWTH Aachen University.

Tynan, B., Lee, M. J. W. \& Barnes, C. (2008). Polar bears, black gold, and light bulbs: Creating stable futures for tertiary education through instructor training and support in the use of ICTs. In Proceedings of World Conference on Educational Multimedia, Hypermedia $\mathcal{E}$ Telecommunications 2008 (pp. 3557-3564). Chesapeake, VA: Association for the Advancement of Computers in Education.

Windham, C. (2005). The student's perspective. In D.G. Oblinger \& J.L. Oblinger (Eds), Educating the Net generation (pp. 5.1-5.16). Washington, DC: EDUCAUSE. [verified 20 Jan 2010] http: / / www.educause.edu/TheStudent\%27sPerspective/ 6061

Wood, D., Bruner, J.S. \& Ross, G. (1976). The role of tutoring in problem solving. Journal of Child Psychology and Psychiatry, 17(2), 89-100.

Zimmerman, B.J. \& Schunk, D.H. (Eds) (1989). Self-regulated learning and academic achievement: Theory, research and practice. New York: Springer-Verlag.

This article is an expanded version of a paper that received an Outstanding Paper Award at ascilite Auckland 2009, gaining the additional recognition of publication in AJET. The reference for the conference version is:

McLoughlin, C. \& Lee, M.J.W. (2009). Personalised learning spaces and self-regulated learning: Global examples of effective pedagogy. In Same places, different spaces. Proceedings ascilite Auckland 2009.

http: / / www.ascilite.org.au/conferences/auckland09/procs/mcloughlin.pdf

Authors: Catherine McLoughlin, Associate Professor, School of Education (ACT) Australian Catholic University, PO Box 256, Dickson, ACT 2602, Australia.

Email: catherine.mcloughlin@acu.edu.au

Mark J.W. Lee, Adjunct Senior Lecturer, School of Education

Charles Sturt University, Locked Bag 588, Wagga Wagga, NSW 2678, Australia.

Email: malee@csu.edu.au

Please cite as: McLoughlin, C. \& Lee, M. J. W. (2010). Personalised and self-regulated learning in the Web 2.0 era: International exemplars of innovative pedagogy using social software. Australasian Journal of Educational Technology, 26(1), 28-43.

http: / / www.ascilite.org.au/ajet/ajet26/mcloughlin.html 